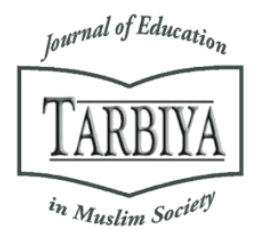

Available online at TARBIYA: Journal of Education in Muslim Society Website:

http://journal.uinjkt.ac.id/index.php/tarbiya

TARBIYA: Journal of Education in Muslim Society, 6(1), 2019, 23-35

\title{
PESANTREN AND LOCAL FEMALE LEADERSHIP IN MODERN INDONESIA
}

\author{
Kusmana \\ Syarif Hidayatullah State Islamic University of Jakarta, Indonesia \\ E-mail:kusmana@uinjkt.ac.id
}

Received: $19^{\text {th }}$ March 2019; Revised: $25^{\text {th }}$ May 2019; Accepted: $28^{\text {th }}$ June 2019

\section{Abstract}

This paper is taking two cases of leadership. The first case deals with a given leadership trait of Nyai Yoyoh Johara, Cintawana Pesantren, Singaparna, Tasikmalaya district, and the other of Nyai Etti Tismayanti, alIkhwan Pesantren, Condong, Setia Negara, Tasikmalaya city. Applying a grounded research method and using Anthony Giddens's perspective of social practice, the study identifies woman's leadership in Islamic educational institutions, from the competition of social force of kodrat and of democracy and feminism. The object of the study is the Muslim woman's leadership at pesantren in the local context. The data used in this study is based on the fieldwork which was done April to November 2010 in both Tasikmalaya district and city. The study found that women apply some strategies and manipulate the hindrances they face dynamically to have a career in the educational realm, in the male world using the limitation imposed by the norm such as kodrat, with several strategies. Modern values as social forces do influence female leadership agency but are implemented through certain rationalization which still maintains the traditional roles of women.

Keywords: kodrat perempuan; pesantren; madrasah; Islamic education; nyai; gender; feminism

\section{Abstrak}

Artikel ini mendiskusikan bagaimana perempuan memimpin di pesantren, baik dalam bentuk kepemimpinan terberi (inherited) atau kepemimpinan yang diraih dengan usaha (achieved leadership) di konteks lokal, Kabupaten Tasikmalaya dan Kota Tasikmalaaya, dengan mengambil dua kasus kepemimpinan. Kasus pertama mendiskusikan jalan (trait) kepemimpinan Nyai Yoyoh Johara, Cintawana Pesantren, Singaparna, Tasikmalaya Kabupaten, dan kedua Nyai Etti Tismayanti, dari Pesantren alIkhwan, Condong, Setia Negara, Kota Tasikmalaya. Dengan menggunakan metode grounded research dan perspektif praktek sosial Anthony Giddens, kajian ini mengidentifiksi kepemimpinan perempuan di Lembaga pendidikan Islam, dari kompetisi kekuatan sosial kodrat perempuan dan kekuatan demokrasi dan feminism. Obyek kajian ini adalah kepemimpinan perempuan Muslim di pesantren dalam konteks lokal. ata yang digunakan dalam peneliti ini adalah berdasar pada hasil penelitin lapngan yang dikerjakan dari bulan April sampai November 2010 di Kabupaten Tasikmalaya dan Kota Tasikmalaya.Kajian ini menemukan bahwa perempuan mengaplikasikan beberapa strategi dan mensiasti halangan yang mereka temui dan mereka secara dinamis bergerak meraih karir dalam dunia pendidikan, dengan menggunakan keterbatasan yang mereka punyai disebabkan pengaruh norma kodrat. Nilai-nilai modern yang berfungsi sebagai kekuatan sosial mempengaruhi agensi kepemimpinan perempuan, tapi pengaruh tersebut dirasionalisasi melalui kekuatan sosial yang masih memelihara peranan tradisional perempuan.

Kata kunci: kodrat perempuan; pesantren; madrasah; pendidikan Islam; nyai; gender; feminism

How to Cite Kusmana (2019). Pesantren and Local Female Leadership in Modern Indonesia. TARBIYA: Journal of Education in Muslim Society, 6(1), 23-35. doi:10.15408/tjems.v6i1.8919.

Permalink/DOI: http://dx.doi.org/10.15408/tjems.v6i1.8919 


\section{Introduction}

Many studies have been conducted to shed the light on Islamic education reform in Indonesia (See for example Karel A. Steenbrink, 1974; Mona Abaza, 1993, 1994; Martin van Bruinessen, 1999; Jajat Burhanuddin, 2007; Zamakshari Dofier, 1982 dan 1999; Noor, Sikand and van Bruinessen [eds.], 2008; Mastuhu, 1994; Faiqoh, 2003; F. van DoornHarder, 2006; Eka Srimulyani, 2012; Arief Subhan, 2009). Their discussions cover many different aspects from institutional development, roles of its agents and leaders, to roles of their alumni and of institutions in society and politics. Regarding Islamic education leadership, many previous studies focused their analysis on the male leadership. Few studies paid attention to the female factor of leadership such as Faiqoh 2003, van Doorn-Harder 2006, Kharirah 2010, and Srimulayni 2012. Pesantren leadership deals with a system, covering not only one individual such as the founder of a pesantren or one who married to a member of Kiai's relatives, but also important members of institutions such as teachers. One important agent of it is woman's leadership in which its agent is commonly called Nyai. This study is a re-visitation to the similar agent but within different context and at the same time complementary to the existing studies. This paper discusses local women leadership in pesantren (Islamic Boarding School) framed in kodrat perempuan lens with a case of Nyais who are active in pesantrens in Tasikmalaya Kabupaten and Kota. (As the focus of discussion in this chapter is women's leadership in Islamic education institution, from now on the three terms Nyai, Ibu and Ummi will be represented by mentioning only Nyai for efficiency. They will be separated only when the case is necessary.) It discusses whether women's leadership follows the development of Indonesian women including Muslim women which are as assumed to have better capacity, more rights, more space and opportunity rather than they were in the past, or it remains stagnant, or increases insignificantly.

Based on the fieldwork and observation of this study in Tasikmalaya Kabupaten and Kota, Muslim women leader in Islamic education institutions can be classified into two types: given (inherited) leader, and achieved leader. Inherited leader may be defined as Muslim female management in pesantren because this female leader is a daughter of the founder or married to one of the close relatives of the founder. Achieved Muslim woman leader may be defined as female Muslim leadership in pesantren because she establishes a pesantren or occupies an important position in it. A Muslim woman leader here refers to a woman who resumes power needed to play an important role at a pesantren and society and people begin to call her this respectful status, usually called Nyai, Ummi or Ibu. In another case, she can be called a muballigha or an ustadza for her role as a religious preacher, but not every muballigha and ustadza can be called Nyai. An ustadzah gains an achieved power most probably on her own in contrast to a Nyai who commonly receives a derived power. An Ustadzah also does not necessarily have an Islamic institution such as a pesantren or Islamic school; instead she has jama'a or members of Majlis Taklims. She is not always from a pesantren family. She may be from an ordinary family who has gone through an adequate Islamic education and or general education. Sometimes she may be supported by her skilful rhetoric talent. (Lies M Marcoes, 1992). In short, most of them are called Nyais.

Muslim woman leader can be a Nyai who is a daughter of a Kyai, married to a Kyai or of a Nyai who has blood tie and has important role in the pesantren and society, or one who is not a daughter of a Kyai but married to a Kyai, or one who established a pesantren and plays as the one. In this paper, the discussion is restricted to two 
examples: of the first example (the Nyai who is a daughter of a Kyai, married to a Kyai, and of the last one (the Muslim woman who established a pesantren). The First example represents the model of given leadership, and the second one represents the model of achieved leadership.

\section{Method}

This study uses Anthony Giddens's perspective of social practice. Social practice in his view is part of his bigger theory of structuration. Structuration is a response to the existing social theories which in Giddens's opinion are reductionist, trapped either in subjectivism or objectivism. It considers the important aspects of subjectivity and objectivity and what lies in between (Anthony G. 2010). It bases its unit of analysis not merely on subjectivity, act, motivation, meaning, and institution, but on social practice where all these aspects are taken into consideration when they are necessary. He defines social practice as a number of living practices which are continuously taking place in space and time for a long time. It is facility and result of the continuous process of reproduction and production of its agents. In other word, discussing agency in Giddens's perspective is identifying situations in which social practices become possible to happen (Anthony G. 2010). It means that how female agents, in this case Muslim women leaders, play role in making a social practice reproduced or produced. What factors are there in making it possible to happen? Social practice is the routine activity or set of routine activity where duality of structure is operative. Agents as the doers of it are out of structure but part of social system. Functionally and substantially social practice is maintained as long as it is needed or used or exercised. It is basically neutral but appreciated for it is good and condemned for it is bad or destructive. It is routine in daily social life. It is continuously reproduced, sometimes modified becoming better, and or produced becoming a new social practice. It places agent within the flexibility and constraints over the situations of the context, sometimes an agent has fair or abundant choices and some other times contrary, very limited choices. However in its limited situation, according to Giddens an agent still have room and opportunity to exercise power and this creates dynamic; a social practice is dependent on internal and external factors. In other words, the constructed kodrat perempuan as a social practice is dependent on internal and external influences to remain, to get modified, or change into a new one.

\section{Results and Discussion}

Given Leadership: The Case of Nyai Yoyoh Johara of Cintawana Pesantren, Singaparna, Tasikmalaya Kabupaten

One different main characteristics of given female leadership from achieved one is that the power is resumed through inheritance, other characteristics seem similar in that every woman leader has to go through experiences of learning, skill improvement, and extension of networking connection. Of these characteristics this female leadership has one thing in common it goes within the influence and authority of her parent. So to some extent, she has basic capital which is significant, that is her family capital. As reflected in the term given through the way of inheritance, given leadership enjoys power and influence of her parent and contributively paves the way in developing her own power and influence through the course of time.

\section{Leadership Trajectory}

Nyai Yoyoh Joharah was born in 1969 in Tasikmalaya, graduated from primary level in 1982, junior high school in 1985, and senior high school in 1988 in her village Cintawana. While she was learning secular 
subjects at general school up to senior high school level, she was also taking religious subjects at her parent pesantren. Having graduated from secular senior high school, she ever continued her religious subjects at another pesantren, Bantar Gedang, Condong, Tasikmalaya Kota, though not for long period of time. After few months learning at this pesantren, the Head of the Pesantren said, it was enough for her to study religious subjects and Arabic language. It is common for a santri before he or she teaches or takes a responsibility to either of establishing or running a pesantren learns or seeks barakah (Ngalap Barakah) from several other pesantrens. Barakah is derived from Arabic language meaning blessed. It is a kind of consent and praying from an authoritative and experienced figure such as a Kyai or society figure given to someone who plans to something such as establishing am educational institution or teaching at it. The impact of the Barakah is actually reasonable and measurable to some extent. If a candidate receives a barakah, it means he or she receives the support and networks of the leading figure. Accordingly, it contributes to his or her efforts of either teaching or leading or establishing a pesantren.

In modern educational traditions we know the similar term, such as comparative studies. Through it, one extends his or her perspective and shares experiences from others by visiting and learning experiences with other similar educational institutions. Johara's study at Bantar Gedang pesantren was not only for the purpose of learning Islamic subjects, but also other educational practices in which Bantar Gedang within the existing pesantrens is known for having excellences in Arabic language teaching and learning process and in managing education for girls.

At her pesantren, Joharoh also improves her religious knowledge by participating in special classes which are given by head of the pesantren or senior teacher for other teachers in general or young teacher or senior students who will be graduated. She usually learns more about it to her husband $\mathrm{KH}$ Rasyidin by asking him when she got difficulty. She also takes classes which are similar with the subjects she usually teaches. Another way of learning she engages, she often prepares the subject she is going to teach. When she gets difficulties she notes them and then she usually asks her husband case by case. Her father $\mathrm{KH}$ Faried Ishak taught this autodidact way of study. In other occasions, she notes questions from students, and asks them to her husband. If the problems remains unanswered which is rarely the case, she asks other senior teachers. When his father lived, she often asked him. After her father passed away, besides her husband, her uncle and elder brother are the figure she refers to when having questions. She also learns from senior Kyais who have two classes consecutively on every Friday night and Saturday night. The given subjects are Hadith, Tafsir and fiqh (Islamic Law) (Nyai Yoyoh J., Personal Communication, Oct 29, 2010).

Having returned from Bantar Gedang pesantren she began developing her teaching skill by teaching elementary and junior high school students several subjects such as theology, tafsir Jalalayn part of Juz 'Amma, and elementary level on the subject of Islamic law, at her Cintawana pesantren since 1988 up to 2000s. Her teaching skill was also nurtured by preaching women occasionally at the Majlis Taklim. After 
about twelve years experience of teaching, she received a bigger responsibility by resuming a leadership as manager or head of pesantren for girls. The pesantren for girls is situated within the area of Cintawana Pesantren, at the right side of it next to other buildings for madrasah and school.

\section{Leadership Experience}

There are at least two angles to identify Nyai's leadership performance in education affairs, from her symbolic role, and from her functional role as teacher and religious preacher. The symbolic role of Nyai Yoyoh Johara plays mainly in the area of the pesantren as mother for female students, because she is responsible for well being and learning process of them. The compliance of this symbolic role for her is genealogically rooted as she is the daughter of the founding father of Cintawana Pesantren, Singaparna, Tasikmalaya Kabupaten for girls. She received the power to lead it by inheritance whose father gave her the mandate before he died. The pesantren for female students is part of it which is situated in the main education institution. The pesantren has both traditional Islamic ways of learning through sorogan and bandongan and madrasa or general school. She felt obliged to implement her father's will to lead the pesantren for female students. The will which was boarded out to her uncle $\mathrm{KH}$ Odang says that "budak awewe diceukel ku Yoyoh" (Female students are led by Yoyoh). Having authorized to lead the pesantren, she dedicated her life in it and restricts her engagement only within this area of efficacy. She for example plays as mother for female students by listening their complaints and problems and by giving them suggestions and some answers. Sometimes she just acts as good listener or some other times she comes up with reward and punishment to respond the students' matters (Nyai Yoyoh J., Personal Communication, Oct 29, 2010).

Another important symbolic role she plays is as a teacher who is always learning to improve knowledge, skill, and networking, though restricted within the internal environment of the pesantren. This role internally inspires students at least to do same. In addition, by giving example, she finds it easier to advice students to spend their time as good as possible. In other words, her influence was gained not only by inheritance but also by effort and consistency in giving good example.

Nyai Yoyoh Joharoh plays her functional role mainly in education sphere. There are three kinds of students. First, students who only study at madrasa or school which constitute the majority, about 1800 students scattered at various programs from early education to senior high school both religious and secular programs. Second kind is students who study at pesantren and madrasa or general school. There are about 270 student male and female students in which about 105 students are female. The last kind, third, is santri (student of pesantren). There are about 80 santris at special class of the pesantren (pesantren takhassus). The 105 female students reside in special compound situated on the right side of the pesantren behind the teachers' and family's houses. Nyai Joharoh's house is on the left side of the boarding for girls on a distant walk. She leads the activities and well being of these 105 female students. Nyai Joharoh teaches religious subjects, monitors and accompanies female students at most of student's time in pesantren activities. From 07.00 to 13.00 they are studying at classes. Apart from teaching, she acts as mother for all female students (Nyai 
Yoyoh J., Personal Communication, Oct 29, 2010). She carries her functional role out within these environments of learning.

In the case of Nyai Yoyoh Joharoh, female leadership she develops is a restricted model in a sense that she focuses her leadership engagement only within the area of Cintawana pesantren. Her social involvement is restricted only in the area of religious teachings and it is also taking place only at the pesantren. Her social leadership engagement does not represent the given woman leader's characteristics. My own fieldwork confirms this conviction as I find many other given women leaders who are more active and dynamic from Nyai Yoyoh Joharoh. Two similar examples are found during my fieldwork: the experience of Nyai Hj. Daliah Mutiara Afandi of Miftahul Huda Pesantren, Manonjaya, Tasikmalaya Kabupaten and Nyai Imas Musidah of Bahru al-'Ulūm, Awipari, Tasikmalaya Kota. Nyai Hj. Daliah Mutiara Afandi, who married to $\mathrm{KH}$ Enjang, one of senior kyais, only attended her basic level of formal school but she studied at her father's pesantren. The pesantren provides her opportunities to practice teaching and preaching either in it or in her network's institutions scattered in Tasikmalaya. After her father passed away she began to develop her own legacy. She has become one of the religious teachers at the pesantren with the busiest schedules of preaching and counseling in many places in Tasikmalaya in the last few decades. She seems to develop her leadership talent by blending her genealogical gift, the pesantren's networks as it has many alumni and branches, and her own efforts to develop skill and knowledge by taking role as religious preacher and nongovernment marriage counselor.
Nyai Imas Mus'idah is another example of Nyai who studied at pesantren and madrasa. She is the first daughter of $\mathrm{KH}$. Busthomi (the former head of Bahru al'Ulūm, Awipari, Tasikmalaya Kota). She studied at her father pesantren during childhood and at Cipasung pesantren while pursued her junior and senior high school. In formal education she participated the six years program of PGA/Pendidikan Guru Agama (Religious Teacher's Training) graduated in 1959. Her first attempt in teaching experience in 1967 is while she was thirteen years old. At the time her father asked her to teach younger female students and members of Majlis Taklim how to recite the Qur'an. Knowing her interest and potentials, her father entrusted her to teach as well as preach on Islamic etiquette (akhlaq), tawhìd (theology) and ta'tim muta allim (teaching how to learn), later on. While her teaching ability was trained in formal school, her religious preaching skill was gained through practice and activism. As the daughter of a famous Kyai with a strong genealogy of her ancestor which goes back to Syekh Abdul Muhyi, the seventeen century figure who was believed to have Islamized the region and its neighboring districts, she discovered herself fond of both teaching and preaching. She remembered after finished her teacher's training 1959 at Cipasung, her father said that "your task now is implementing your knowledge and skill at the pesantren." Since 1967, teaching became her career as she was assigned by the state to be a teacher at Religious Primary School (Madrasa Ibtidaiyyah). In the course of time she also taught different levels of schools from elementary to senior high school level. Besides teaching she was also fond of organizational activities. She got involved in NU's wing organizational activities such as Fatayat and Muslimat NU 
and participated in political practice where she affiliated to PPP and PKB since Reformasi era (Nyai Ida M., Personal Communication, July 29, 2010).

However the case of Nyai Yoyoh Joharoh is important. The case of Nyai Yoyoh represents one kind of female leadership education institutions which is dominant among Islamic traditional pesantren. It qualifies certain characteristics of leadership which I call it as traditional female leader of pesantren. This traditional female leadership is still very much influential by traditional forces that are patriarchy and constructed kodrat perempuan. Patriarchy holds on values of the patriarchal family values which prioritizes the primacy of husband over wife in terms of gender relations, and the male world superiority in terms of the constructed kodrat Perempuan. In these values, women though situated at the area deemed appropriate with their nature at education engagement, are under man's superiority and patriarchy. They are working, engaging and participating in education spheres with the support of male counterparts, yet their supports are usually translated within the man's interest, making female leadership working under the shadow of male counterpart's engagement. The case of Nyai Yoyoh Joharoh shows a rather passive way of receiving leadership where she resumed it by inheritance from her father, and receiving consent and support from her husband accordingly. She received a will which asked her to lead pesantren for girls. She also often learns religious knowledge and her husband experience by asking him or participating in his special classes for other teachers.
Achieved Leadership: The Case of Nyai Etti Tismayanti, al-Ikhwan pesantren, Condong, Setia Nagara, Tasikmalaya Kota

The trajectory of Muslim women leaders in achieved female leadership does not always have the privileged of the given leadership has. In many cases, a woman leader has to build skill, knowledge and networking by her own effort. Many women leaders receive additional power and influence when they get married to a husband who is influential due the nature of the patriarchal society which places man as the head of the family, and which prioritizes them as leaders of many occupations and careers. In contrast, in many other occasions, women's leaders have opportunity and space to pave their leadership trajectory since early age of education due to the policy of education of Indonesian government which has been treating gender role the same since its independence in 1945. Normatively girls have the same rights with boys to participate in education program up to the highest level. Though in the practice the figure is like pyramid for woman's education participation, women certainly have developed ever since, following their male counterparts. The policy though not as effective as for girls at general schools, it certainly provides space and opportunity for girls at pesantrens to improve at least in following the basic education qualification every citizen should have. The policy is even better as the policy of 12 years basic education is moving to be a national policy. When it happens, it will influence basic education qualification for girls at pesantrens too. It means that women's basic capacity will be improved. Accordingly women's qualifications will be improved too.

In this occasion, the discussion will be restricted on achieved female leadership in the case of Muslim woman leader who is trained in Islamic studies and married to a man trained in the same discipline and both established a 
pesantren. The achieved female leadership is characterized by the fact that a woman has a weaker capital than the given female leadership which on one hand, this is one deficit of it, yet on the other hand, it provide space and room to fight or make necessary efforts to qualify herself with knowledge, skill and network she needs. A case in point is Nyai Etti Tismayanti, wife of KH. Mukhsin al-Sadili, head of al-Ikhwan Pesantren, Condong, Setia Nagara, Tasikmalaya Kota.

\section{Leadership Trajectory}

Nyai Tismayanti was born on August 10, 1957 in Ciakar, Cijulang, Ciamis regency. Her father, $H$. Masfuddin and mother $\mathrm{Hj}$. Siti Khadijah are religious. Her parent sent all their four children to school up to undergraduate level. Nyai Tismayanti finished her primary level in her village, junior level in Cijulang, senior level in education one year in Pangandaran and six years in Sukamanah Tasikmalaya, graduated in 1974. She continued to higher education for three years programs at Tarbiyyah YPPI, Tasikmalaya and graduated in 1978. Married to Mukhsin al-Sadili in 1977, (now known as KH., as head of al-Ikhwan pesantren) when he was student at IAIN Sunan Kalijaga, Yogyakarta. The couple is state employee as teacher. She formally became a Nyai after she and her husband established al-Ikhwan pesantren, Condong, Setia Nagara, Tasikmalaya Kota in 1989. The land where the pesantren was built was endowed by $\mathrm{Hj}$ Djuhaenah, a local female donator.

Nyai Tismayanti continued her education in S1 at STAI Tasikmalaya after having been working as the state employee for a while and graduated in 1991. She pursued magister program at UIN Sunan
Gunungjati Bandung majoring in Islamic education and finished in 2006. She directly continued to S3, and graduated from Doctoral level in 2008. In addition to her primary task as a state employee as a teacher, she is also an active Nyai at the pesantren heading school programs in it. Through education engagement, she developed her knowledge, skill and networking at both state school's networks where she works daily or private schools where she runs and manage pesantren and schools in it. She is also active in different activities in mass organizations like Fatayat and Muslimat, in majlis taklim bot at neighbouring areas or at regency mosque, local woman organization, GOW/Gabubungan Organisasi Wanita (Union of Women's Organizations) (Nyai Etti T., Personal Communication, Auguts 24, 2010).

\section{Leadership Experience}

One strong symbolic role Nyai Tismayanti plays is as successful Muslim woman in education training. She pursued her education up to the highest level, S3 majoring in Islamic education. Her success in education training becomes inspiration for others, because there are still few Muslim women at traditional pesantren in Tasikmalaya who did it. It was also so at basic education institution level in general. However, her success inspires other women, sending a message that if they want it they could most probably do too as she did. It is of course with measurable probability of pursuing it such as having opportunity, capacity, and fund, in addition to assertiveness and endurance, to carry it out.

Another important symbolic role Nyai Tismayanti has is as an active mother. She plays not only as the mother of her children, but also of her students at pesantren specifically that of madrasah and vocational 
school organized by the pesantren. To some extent it may be also said as mother of community at least within the environment of members of majlis taklim in which she gets involve in more than 20 majlis taklim in the city. As a mother in her family, she considers her husband as the head of the family following the existing norm of patriarchy, and doing house hold and children rearing and bearing, but with addition she also shares other family matters including family income. Being her status the same with her husband -the state civil servant as educator, means she also plays role as the breadwinner contributing to the family income. With the qualification of S3 she is actually superior compared to her husband's education background, and it paves her way to take hold in managing madrasah and vocational school of the pesantren.

What does Nyai Etti Tismayanti leadership represent in terms of mother agency in the context of traditional Islamic education institution? It can be said that she represents a new traditional profile of woman's leader which qualifies modern values. Her long and highest level of education training in modern institutions transforms her into new level of capacity, and skill which gives stronger capital to take role in her public engagement. Accordingly she has more potency to manipulate successfully barriers she faces by exercising her power and influence which is competitive and difficult to beat. In addition to these qualifications she is also one of the founding father of the pesantren, and with all this makes her agency stronger.

Nyai Etti Tismayanti leadership evolves from teaching certain subjects of Islamic sciences such as akhlaq, fiqh, tauhid, Qur'anic recitation, and interpretation,
Hadīth studies, etc., to management of education institutions. In general school she teaches what so called Pelajaran Agama which consists of introductions to fiqh, tauhid, akhlaq, the Qur'an, Hadīth, and history of Islam. As a state civil servant, she taught at primary school and then at junior high school, but now she teaches at senior high school, SMAN 1 Tasikmalaya, the same subjects. She formally became a Nyai after she and her husband established alIkhwan pesantren in 1989. The pesantren has early age educational program, traditional pesantren, Sekolah Menengah Kejuruan/SMK (Senior Vocational High School), Youth Mosque Organization and majlis taklim. There are about 95 pesantren's students and 40 students of the SMK. Nyai Tismayanti's role at the institution is vital. She leads all formal educational activities there and preaches twice a month at the pesantren's majlis talim. She also shares her knowledge and skill with santris (the pesantren's students) similar Islamic sciences subjects given in general classes with additional references and levels which are commonly used at traditional pesantren.

In society, she also regularly preaches at about 20 other majlis taklims scattered in the city. As cadre of NU she has been active in either Fatayat or Muslimat. She was ever elected as head of Fatayat NU in the city for two periods, from 2002 to 2009. At the moment she is active at Muslimat NU as head of Research Development. She regularly gives religious sermons at Tasikmalaya's Masjid Jami (Great Mosque) once a month. Her activism seems reach beyond the traditional boundary of the NU's main organization. Her status as a state employee helps her in playing this role where she deals with a larger public, i.e. 
teaching at madrasa and general school. In addition, since 2007 she had been assigned to be head of Gabungan Organisasi Wanita/GOW (the Fusion of Women Organizations). In her case, becoming a Nyai was not merely because she married to a husband in 1977 whose destiny to be Kyai was gained later but also she participated in establishing and developing the pesantren. In short, she also achieved her influence by her own efforts through educational and social engagement (Nyai Etti T., Personal Communication, Auguts 24, 2010).

How Nyai Etti Tismayanti leadership is perceived is interesting to note due to the fact that her expertise and achievement to one point is operative within the context of strong patriarchal values. Reluctance towards her leadership performance is found for example from her own staff due to her too dominant role in managing the school. The way he sees this point is from the stand of the assumed appropriate gender relation, considering this dominion as contravening the ideal gender role in the city where this dominion is commonly held by men. Feeling threatened of male agency is one common problem woman usually encounters when she assumes certain influence in the male world. In her experience, she plays her agency restrictively in the matter of pesantren allowing the role of her husband as the head of pesantren formally dominant. By doing this, she is able to focus her leadership in managing general school at it. Her capital in it is well trained as the state educator civil servant her education trajectory has been constructed from being elementary teacher up to as senior high school teacher.

Nyai Etti Tismayanti's case represents another model of Muslim woman leader which I call it as modernized traditional woman leader. Born from traditional Muslim family who accept modernity by sending their children including the Nyai herself to modern school, she internalizes this norm and extends it by pursuing her education up to the highest level. The modernized norm is characterized by its persistence to traditional values, and at the same time opening up its probability to accept modern ones as long as they can go along hand by hand with them. It is reflected for example in the way she manipulates the constraint of the perception of kodrat perempuan. Different from Nyai Yoyoh Joharoh who deploys a passive strategy, Nyai Etti Tismayanti uses a more active one, yet maintaining certain tasks which are considered traditional such as doing households and paying attention to the well being and education of their children. For example, she prepares the meal for the family in the morning, sweeps the front yard of her house, and makes sure their children education. The way she does them is either she does herself or asks students to do so. In terms of leadership at pesantren she plays a functional task by managing general school in addition to her symbolic role as the Nyai of the pesantren as mentioned above (Nyai Etti T., Personal Communication, Auguts 24, 2010).

\section{The Two Cases and Discourse of Muslim Woman's Leadership}

The two cases discussed in this paper represent Muslim woman's encounter with modernity in which the two react similarly but with different way of accepting it. In the case of Nyai Yoyoh Joharoh, modernity is accepted and used to support the pesantren's persistence of maintaining traditional values re produced by traditional pesantren by with???? it is the nature of the institution. It is a general picture of Islamic educational institution's stand in 
Indonesia in responding modernity. It is another fact that supports the accordance of Islam with modernity in which some consider this kind of Islamic education institution as in antiquity and contrary to modernity (Farish A.N., Yonginder S., Martin Van B., 2008). Within the area of Islamic sciences and values, the case of Nyai Joharah reflects of perseverance of what are considered as Islamic, and of taking advantage modernity restricted only into management, facility and to some extent on share values such as discipline. Nyai Joharoh herself does not get involved in managing general school the pesantren has. She only deals with the task of pesantren to equip every student to master basic Islamic sciences, daily religious ceremonies and etiquette.

In the case of Nyai Tismayanti, modernity is also accepted and at the same time implemented to manage the education institution particularly that of general school the pesantren has. The difference of this case from the first case is that she not only plays her agency as guardian of traditional values in the pesantren and in general schools where she teaches but also as agent of social change by placing herself in the front of education management as head of the vocational school in the pesantren. In addition, her choice of opening vocational school may be interpreted as an evidence of her seriousness as agent of social change by lifting up the pesantren tradition of giving student certain simple skills such as doing the lands of Kyais, house chores, or babysitting the Kyais children to more formal structurized training program such as SMK or vocational senior high school.

Eka Srimulyani's study which identifies honor and modesty as traditional standard misses the actual cause that directs one's consciousness and action. She only identifies some implications of it in Muslim women's daily life (Eka S., 2012). Traditional norms characterized by the following values modesty, politeness, companion to male counterpart and speaking shortly. These values are universal in pre modern era in which they were, are, and will be reproduced particularly in the context of patriarchal societies such as Indonesia. In contrast, the cause of it is deeper than that which can be anchored to Muslims' perception of Kodrat Perempuan or constructed woman's nature. In both cases, their perception of kodrat plays not only in their consciousness such as motivation, reasoning and intension of their speech and action, but deeper that in their unconsciousness such as spontaneous speech and action. Reality in this perspective is divided into two areas deemed appropriate with kodrat and areas deemed not appropriate with it. It means that constructed kodrat perempuan directs not only honor and modesty of woman's role and performance, but also areas of engagement. In this matter, the case of Nyai Joharoh exemplifies traditional role of Muslim woman which influences her leadership, meanwhile the case of Nyai Tismayanti exemplifies more rationalized traditional role of Muslim woman's leader which allows certain modern values to extend their engagement.

Accordingly the two cases show certain degree of influence of the constructed kodrat to the spectrum of woman's leader performance in that Nyai Joharoh's area of engagement is more restricted in only within the pesantren area than Nyai Tismayanti's one in which she reaches beyond the pesantren area to both within the main organization of NU and out of it. Nyai Joharoh's leadership experience is commonly found where female leadership develops within the constraints of the umbrella institutions. From within pesantren and madrasa women leaders get involved in areas of activities conducted by the pesantren or madrasah such as giving religious subjects at classes, homes, and corners of a mosques, and majlis taklim. In other cases, Muslim women leaders also participate in the wing institutions' activities such as Aisyah 
(Muhammadiyah's female wing organization), Persistri (Persis's female wing organization), Fatayat (NU's organization for girls) or Muslimat NU (NU's organization for women). The extension of their engagement may reach organizations out of their organizations but usually related such as local majlis taklim organization like BKMT (Badan Koordinasi Majlis Taklim/Majlis Taklim Coordination Body), or local women's organization such as GOW (Gabungan Organisasi wanita/Women's Organizations Group) such what experienced by Nyai Tismayanti. Moreover, as shown in other studies Muslim women leaders play in larger area of engagement either as judge and member of parliament (Eka Srimulyani 2012 and my field work), as head of public office -head of village, of ward (my fieldwork), mayor of head of regency, governor, minister, or even president.

\section{Conclusion}

The two cases exemplify two different female educational leadership experiences, yet both accept democracy with different accentuation. Nyai Yoyoh Joharoh's leadership experience informs a traditional model of Muslim woman leader in which the influence of constructed kodrat perempuan is felt strong. Female agency is operative within the constraint of the supremacy of male determinacy nurtured by norms which support male world. Though pesantren is the area deemed appropriate for kodrat perempuan, its implementation in the context of patriarchal values necessitates woman leader to negotiate with it. In her case, she adjusts it accordingly.

Meanwhile Nyai Etti Tismayanti's leadership experience shows a more progressive picture yet still the same with Joharoh's model, i.e. traditional model of Muslim woman leader. The progressive aspect of her leadership is rationalization of some traditional values. It is influenced by modern values. Nyai Tismayanti herself accepts as well as takes advantage of them by pursuing her education to the highest level. Furthermore she deploys them in her educational leadership engagement as well as social one.

In short, the two cases represent only part of female leadership discourse at large which occupies larger areas of engagement including to professional areas of engagement to political ones. It seems that Muslim women leaders deploy strategies to manipulate the constraint of social force such as perception of kodrat perempuan either by a wait-and-see strategy, spouse and family consent, or by showing affirmative attitude. .

\section{References}

Burhanuddin, J. (2002). Ulama Perempuan Indonesia. Jakarta: Gramedia Pustaka Press and PPIM IAIN Jakarta.

Dofier, Z. (1982). Tradisi Pesantren: Studi tentang Pandangan Hidup Kyai. Jakarta: LP3ES (Lembaga Penelitian, Pendidikan dan Penerangan Ekonomi dan Sosial).

Djajadiningrat-Nieuwenhuis, M. (1987). Ibuism and Priyayization: Path to Power? In Indonesian Women in Focus: Past and Present Notions? Edited by E. LocherScholten and A. Niehoff. DordrechtHollad: Foris Publication: 43-51.

Faiqoh. (2003). Nyai: Agen Perubahan di Pesantren. Jakarta: Kucica

Kharirah, K. (2010). The Women's Movement in Indonesia's Pesantren: Negotiating Islam, Culture and Modernity. A Thesis, the Center for International Studies, Ohio University. 
Marcoes, Lies M. (1992). The Female Preacher as Mediator in Religion: A Case Study in Jakarta and West Java. Women and Mediation in Indonesia, edited by Sita van Bemmelen (et.al). Leiden: KITLV Press.

Mastuhu. (1994). Dinamika Sistem Pendidikan Pesantren. Jakarta: INIS.

Noor, F. A., Sikand, Y., Bruinessen, m. v. [eds.] (2008). The Madrasa in Asia: Political Activism and Transnational Linkages. Amsterdam: Amsterdam University Press.

Srimulyani, E. (2007). Negotiating Public Space: Women and the Pesantren in Jombang East Java. A Thesis (Ph.D.). Sydney: Institute for International Studies, University of Technology.

Srimulyani, E. (2008a). Negotiating Public Space: Three Nyai Generations in a Jombang Pesantren. Indonesian Islam in a New Era: How Women Negotiate Their Muslim Identities editeb by Susan Blackburns. Melbourne: Monash Asia Institute: 119-37.

Srimulyani, E. (2008b). Pesantren Seblak in Jombang East Java: Women's Educational Leadership. Review of Indonesian and Malaysian Affairs. 42 (1): 81-106.
Srimulyani, E. (2009). Women Leadership in Islamic Educational Institutions in Java and Aceh: A Comparison between Pesantren in Java and Dayah in Aceh. Kultur: the Indonesian Journal for Muslim Cultures. 4 (2): 159-73.

Steenbrink, Karel A. (1974). Pesantren, Madrasah, Sekolah: Pendidikan Islam dalam Kurun Modern. Jakarta. LP3ES/Lembaga Penelitian, Pendidikan dan Penerapan Ekonomi dan Sosial.

Subhan, A. [et.al]. (2003). Citra Perempuan dalam Islam. Jakarta: Gramedia Pustaka Utama

van Bruinessen, Martin. (1995). Kitab Kuning, Pesantren dan Tarekat: Tradisi-tradisi Islam di Indonesia. Bandung: Mizan.

van Bruinessen, Martin. (2006). "Divergent Paths from Gontor: Muslim Educational Reform and the Travails of Pluralism in Indonesia," in On the Edge of Many Worlds edited by F.L. Bakker and Jan Sihar Aritonang. Zoetermeer: Meinema.

van Doorn-Harder, Pieternella. (2006). Women Shaping Islam. Indonesian Muslim Women Reading the Qur'an. ChampaignUrbana \& Chicago: University of Illinois Press. 